\title{
Rapid Regeneration of Lettuce from Suspension Culture
}

\author{
Whei-Lan Teng', Yann-Jiun Liu, and Tai-Sen Soong \\ Agricultural Biotechnology Division, Development Center for \\ Biotechnology, 81 Chang Hsing Street, Taipei, Taiwan, R.O.C. \\ Additional index words. Lactuca sativa, cell suspension, callus quality, carbohydrate, \\ growth regulator, light
} Abstract. An efficient method for the regeneration of shoots directly from cell sus-
pensions of three commercial cultivars of lettuce (Lactuca sativa L. cv. Great Lakes
$659-700$, Salad Bowl, and Prize Head) is described. Cell suspensions were prepared by
osterizing cotyledon-derived callus for 60 seconds. The effects of callus quality, light
intensity, carbohydrate type and concentration, auxins, and cytokinins on cell growth
and differentiation in the suspension culture were examined. Among these factors,
callus quality and carbohydrates were the most critical. The optimal medium for re-
generation of shoots in suspension culture was SH (Schenk and Hilderbrandt) basal
medium containing 1000 mg myo -inositol/liter, $1.5 \%$ glucose, $0.44 \mu \mathrm{M}$ BA, and 0.54
$\mu$ MAA. The pH of the medium was adjusted to 5.8 . Under such condition, hundreds
of shoots could be produced from 50 to 55 mg (dry wt) of cell aggregates within 2
weeks. Chemical names used:oflaphthaleneacetic acid (NAA); indole3-acetic acid
(IAA); 6-benzylaminopurine (BA).

In vitro regeneration of lettuce usually takes weeks or months, depending on explant source and culture medium. Shoots were observed on leaf explants of 'Calmar' head lettuce in 2 weeks when cultured on Miller's medium with $27 \mu \mathrm{M}$ NAA and $2.3 \mu \mathrm{M}$ (Koevary et al., 1978). Cotyledon explants from 'Grand Rapids' regenerated after 3 weeks of culture on MS medium (Murashige and Skoog, 1962) containing $28.5 \mu \mathrm{M}$ IAA and $2.3 \mu \mathrm{m}$ kinetin (Webb et al., 1984). Callus grown from protoplasts isolated from cotyledons usually took 2 months to regenerate (Nishio et al., 1988).

Received for publication 30 Sept. 1991. Accepted for publication 27 Mar. 1992. This research was supported by the U.S. Dept. of Agriculture and the Council of Agriculture, Taiwan. Project no. TW-AES-42. The cost of publishing this paper was defrayed in part by the payment of page charges. Under postal regulations, this paper therefore must be hereby marked advertisement solely to indicate this fact.

'To whom reprint requests should be addressed.
Most in vitro regeneration of lettuce has been carried out on solid media. The time and labor cost for separating plantlets from solid medium and undifferentiated callus before transplanting is of great concern. For application of in vitro propagation of lettuce to artificial seed production, this issue becomes very important. [Small plantlets or protocorms can be used in the development of artificial seed technology (Nishimura et al., 1988).] Therefore, regeneration in suspension culture system would be advantageous.

Suspension cultures of lettuce have been established; however, shoot regeneration did not take place until cell clumps or callus from cell suspensions were transferred onto solid media (Alconero, 1983; Sasaki, 1975). The time required for regeneration was 5 weeks (Sasaki, 1975) or 3 months (Alconero, 1983). We report here development of a suspension culture system for rapid regeneration of three commercial lettuce cultivars.

Seeds of 'Great Lakes 659-700', 'Salad 
Table 1. Effects of callus quality on shoot and callus growth in lettuce suspension culture.

\begin{tabular}{|c|c|c|c|c|}
\hline \multirow{3}{*}{$\begin{array}{l}\text { Callus } \\
\text { appearance } \\
\text { Brownish }\end{array}$} & \multicolumn{2}{|c|}{ Shoots } & \multicolumn{2}{|c|}{ Dry wt } \\
\hline & \multicolumn{2}{|c|}{$\begin{array}{l}>0.5 \mathrm{~cm} \text { Total } \\
\text { (no./flask) }\end{array}$} & \multicolumn{2}{|c|}{$\begin{array}{l}\text { Shoot Callus } \\
\text { (mg/flask) }\end{array}$} \\
\hline & $\mathrm{d}^{2}$ & $0 \mathrm{~d}$ & $0 \mathrm{~b}$ & $55 \mathrm{~b}$ \\
\hline White & $1 \mathrm{~d}$ & $3 \mathrm{~d}$ & $14 \mathrm{~b}$ & $173 \mathrm{a}$ \\
\hline Green & $118 \mathrm{~b}$ & $218 \mathrm{~b}$ & $192 \mathrm{a}$ & 149 a \\
\hline $\begin{array}{l}\text { Green with } \\
\text { buds }\end{array}$ & $141 \mathrm{a}$ & 251 a & 152 a & $140 \mathrm{a}$ \\
\hline $\begin{array}{l}\text { Green with } \\
\text { shoot }\end{array}$ & $91 \mathrm{c}$ & $179 \mathrm{c}$ & 156 a & $156 \mathrm{a}$ \\
\hline
\end{tabular}

'Mean separation within columns by Duncan's new multiple range test, $P=0.05$.

Table 2. Effects of glucose and sucrose concentrations on shoot and callus growth in lettuce suspension culture.

\begin{tabular}{lcccc}
\hline \hline \multirow{2}{*}{$\begin{array}{l}\text { Sugar } \\
\text { concn } \\
(\%)\end{array}$} & \multicolumn{2}{c}{ Shoots } & \multicolumn{2}{c}{ Dry wt } \\
\cline { 2 - 6 } & $\begin{array}{c}>0.5 \mathrm{~cm} \text { Total } \\
\text { (no./flask) }\end{array}$ & $\begin{array}{c}\text { Shoot Callus } \\
\text { (mg/flask) }\end{array}$ \\
\hline Sucrose & & & & \\
0.0 & 0 & 5 & 5 & 16 \\
1.5 & 48 & 117 & 84 & 214 \\
3.0 & 73 & 168 & 177 & 225 \\
6.0 & 81 & 170 & 192 & 202 \\
8.0 & 33 & 131 & 141 & 179 \\
Significance & $* *$ & $* *$ & $* *$ & $* *$ \\
$\quad$ Linear & $* *$ & $* *$ & $* *$ & $* *$ \\
$\quad$ Quadratic & & & & \\
Glucose & 0 & 5 & 5 & 16 \\
0.0 & 75 & 175 & 151 & 140 \\
1.5 & 65 & 154 & 207 & 133 \\
3.0 & 40 & 81 & 108 & 79 \\
6.0 & 13 & 57 & 47 & 26 \\
8.0 & & & & \\
Significance & NS & NS & NS & NS \\
$\quad$ Linear & $* *$ & $* *$ & $* *$ \\
$\quad$ Quadratic & $*$ & $* *$ & $* *$ & $* *$ \\
Sugar & $* *$ & $* *$ & $* *$ & $* *$ \\
Concn & $* *$ & $* *$ & $* *$ & $* *$ \\
Sugar $\times$ concn & &
\end{tabular}

${ }_{\text {NS,*,*** Nonsignificant or significant at } P=0.05}$ and 0.01 , respectively.

Table 3. Effects of light intensity on shoot and callus growth in lettuce suspension culture.

\begin{tabular}{lllll}
\hline \hline & \multicolumn{2}{c}{ Shoots } & \multicolumn{2}{c}{ Dry wt } \\
\cline { 2 - 5 } $\begin{array}{l}\text { Quanta } \\
\left(\mu \mathrm{mol} 1 \cdot \mathrm{m}^{-2} \cdot \mathrm{s}^{-1}\right)\end{array}$ & $\begin{array}{c}>0.5 \mathrm{~cm} \text { Total } \\
(\text { no./flask })\end{array}$ & $\begin{array}{c}\text { Shoot Callus } \\
(\mathrm{mg} / \mathrm{flask})\end{array}$ \\
\hline 0 & $\mathbf{7 7}$ & 130 & 127 & 149 \\
8 & 73 & 170 & 197 & 116 \\
16 & 76 & 225 & 223 & 92 \\
Significance & $\mathrm{NS}$ & $* *$ & $* *$ & $* *$ \\
$\quad$ Linear & $\mathrm{NS}$ & $\mathrm{NS}$ & $\mathrm{NS}$ & $\mathrm{NS}$ \\
Quadratic & &
\end{tabular}

${ }^{\mathrm{NS}, * *}$ Nonsignificant or significant at $P=0.01$, respectively.

Bowl', and 'Prize Head' lettuce were surface-sterilized with $1 \% \mathrm{NaOCl}$ for $5 \mathrm{~min}$, followed by a thorough rinse with sterile distilled water. Seeds were then aseptically germinated on SH (Schenk and Hildebrandt, 1972) basal medium. Cotyledon explants were used to induce callus. For callus induction, SH basal medium was used, supplemented with $3 \%$ sucrose, $1000 \mathrm{mg}$ myo -inositol/liter, and growth regulators. The growth regulators for 'Great Lakes 659-700' were 0.54

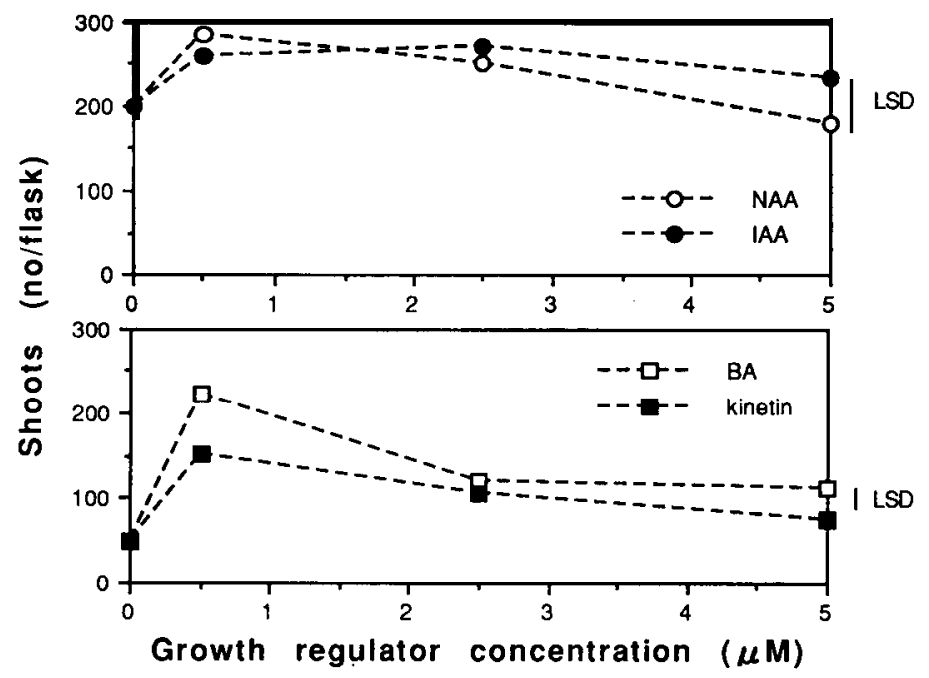

Fig. 1. Influence of auxin and cytokinin concentration on shoot regeneration of 'Great Lakes 659700' lettuce, (A) NAA and IAA with $0.46 \mu \mathrm{m}$ kinetin. (B) BA and kinetin with $0.5 \mu \mathrm{m}$ NAA. Mean separation at a given concentration by LSD test, $P=0.05$.

$\mu \mathrm{M}$ NAA and $2.3 \mu \mathrm{M}$ kinetin; for 'Salad Bowl' and 'Prize Head', they were $0.54 \mu \mathrm{M}$ NAA and $0.44 \mu \mathrm{m} \mathrm{BA}$. The $\mathrm{pH}$ of the culture medium was adjusted to 5.8 before autoclaving. Callus was subcultured at 3-week intervals on the same medium and maintained in a growth room under a constant $25 \mathrm{C}$ and $24 \mathrm{~h} \cdot$ day $^{-1}$ illumination provided by cool-white fluorescent light at an intensity of 8 to $10 \mu \mathrm{mol} \cdot \mathrm{m}^{-2} \cdot \mathrm{s}^{-1}$.

Inoculum for the suspension cultures was prepared by osterizing callus with liquid culture medium for $60 \mathrm{sec}$. The inoculum, composed of single cells and aggregates of a few cells, could pass through 400- $\mu$ m (42-mesh) stainless steel sieves. The liquid culture medium, if not mentioned specifically, was the same as the callus induction medium, but without agar. For each treatment, there were four replications. All experiments were conducted three times. Data from all three experiments were used for statistics. Cell suspensions were prepared by pipetting $2 \mathrm{ml}$ of inoculum into a $125-\mathrm{ml}$ flask with $30 \mathrm{ml}$ of liquid culture medium. The average dry weight of $2 \mathrm{ml}$ of inoculum was 50 to 55 $\mathrm{mg}$. All inoculated flasks were placed on orbital shakers at $110 \mathrm{rpm}$ in the same growth room as for callus maintenance.

After 2 weeks of culture, all flasks were removed from the shaker. Shoots and undifferentiated callus were separated from liquid medium by filtration. The shoots were then counted and separated from the undifferentiated callus. The dry weights of both shoots and undifferentiated callus were determined after being held $24 \mathrm{~h}$ at $100 \mathrm{C}$.

To determine optimal conditions for the suspension culture, factors that influence cell growth and differentiation were tested, including callus quality, light intensity, carbohydrates, and growth regulators. 'Great Lakes 659-700' was used in these experiments.

Glucose and sucrose concentrations ranging from 0 to $8 \%$ were selected to test the relationship between concentration and re- generation. To obtain an optimal mixture of growth regulators, NAA/IAA and BA/kinetin at 0 to $5 \mu \mathrm{M}$ were selected. Except for the tested carbohydrates and growth regulators, the culture medium was the same as the callus induction medium. The inocula were prepared by osterizing callus with medium devoid of the supplement to be tested.

Few previous research papers have dealt with the relation between the characteristics of callus and subsequent shoot regeneration. Alconero (1983) reported that satisfactory cell suspensions were prepared from the soft, white-to-cream-colored, friable callus. Such cell suspensions regenerated after transfer to solid medium. In our study, the most critical factor affecting shoot regeneration was the source of inoculum. After 3 weeks of callus induction, callus could be classified into five groups: brownish, white, green, green with buds, and green with shoots. Only suspension cultures derived from green callus (with or without preformed buds or shoots) were able to regenerate shoots (Table 1). Suspension cultures derived from green callus with buds regenerated more shoots than those from other calli. Within 2 weeks, 250 shoots were regenerated, with 140 longer than $0.5 \mathrm{~cm}$ (Table 1). Thus, green callus with buds was selected as the plant material for the experiments designed to optimize culture conditions.

Sucrose and glucose are widely used as a carbon source for in vitro culture, because most plant cells grow best with these sugars (Maretzki et al., 1974). For lettuce, the highest regeneration frequency occurred at $3 \%$ or $6 \%$ sucrose of $1.5 \%$ glucose (Table 2). Glucose induced more shoots and less callus growth than sucrose.

The influence of growth regulators on regeneration of shoots has been investigated by others, among them Doerschug and Miller (1967), who observed shoot formation only when kinetin was present in lettuce culture media. On the contrary, we found that growth regulators were not critical for regeneration. 
Table 4. Effects of liquid and solid medium on shoot regeneration and callus growth of lettuce.

\begin{tabular}{|c|c|c|c|c|}
\hline \multirow[b]{3}{*}{ Medium and cultivar } & & & \multicolumn{2}{|c|}{ Dry wt } \\
\hline & \multicolumn{2}{|c|}{ Shoots } & \multirow[t]{2}{*}{ Shoot } & \multirow[t]{2}{*}{ Callus } \\
\hline & $>0.5 \mathrm{~cm}$ & Total & & \\
\hline \multicolumn{5}{|c|}{ (no. /flask) } \\
\hline \multicolumn{5}{|l|}{ Liquid' } \\
\hline Great Lakes 659-700 & 72 & 222 & 147 & 117 \\
\hline Salad Bowl & 65 & 226 & 119 & 276 \\
\hline Prize Head & 61 & 231 & 143 & 264 \\
\hline Significance & $\mathrm{NS}^{\mathrm{w}}$ & NS & NS & NS \\
\hline \multicolumn{5}{|c|}{ (no/ldish) } \\
\hline \multicolumn{5}{|l|}{ Solid $^{y}$} \\
\hline Great Lakes 659-700 & $55 \mathrm{a}^{\mathrm{w}}$ & $91 \mathrm{a}$ & & \\
\hline Salad Bowl & $35 \mathrm{a}$ & $104 \mathrm{a}$ & & \\
\hline Prize Head & $10 \mathrm{~b}$ & $44 \mathrm{~b}$ & & \\
\hline
\end{tabular}

${ }^{2}$ Two milliliters of inoculum was pipetted into each flask.

One milliliter of inoculum was pipetted onto each petri dish.

"Mean separation within columns by Duncan's new multiple range test, $P=0.05$.

There were 60 shoots regenerated in the culture medium without any growth regulator. Addition of kinetin/BA and NAA/IAA, however, could significantly enhance regeneration. The best combination of growth regulators was $0.54 \mu \mathrm{M}$ NAA and $0.44 \mu \mathrm{M} \mathrm{BA}$ (Fig. 1).

Light is another important factor for shoot regeneration. Shoots have been reported to form more frequently on explants incubated in the light than on those in darkness (Kadkade and Seibert, 1977; Sasaki, 1979; Webb et al., 1984). Koevary et al. (1978) reported that $5 \mu \mathrm{mol} \cdot \mathrm{m}^{-2} \cdot \mathrm{s}^{-1}$ of light resulted in root initiation without shoot development, while $10 \mu \mathrm{mol} \cdot \mathrm{m}^{-2} \cdot \mathrm{s}^{-1}$ accelerated shoot development. Our results indicated that light intensity had no effect on the differentiation of cells into shoots or roots, it only influenced regeneration frequency. Shoot count increased as light intensity increased from 0 to $16 \mu \mathrm{mol} \cdot \mathrm{m}^{-2} \cdot \mathrm{s}^{-1}$ (Table 3). However, the number of shoots longer than $0.5 \mathrm{~cm}$ did not differ between those in darkness and those in light.

For each individual experiment, several shoots were found to have formed roots during 2 weeks of culture. The shoots without roots could form roots in 1 month either in liquid or on solid hormone-free medium.

In summary, the optimal combinations for regeneration of 'Great Lakes 6.59-700' are: green callus with buds, $\mathrm{pH} 5.8,1.5 \%$ glucose, $0.54 \mu \mathrm{M}$ NAA, $0.44 \mu \mathrm{M}$ BA, and 20 $\mu \mathrm{mol} \cdot \mathrm{m}^{-2} \cdot \mathrm{s}^{-1}$ of light intensity. When this condition was used to culture 'Salad Bowl' and Prize Head', they regenerated as well as 'Great Lakes 659-700' in liquid medium. However, on solid medium, the regeneration frequency of 'Salad Bowl' was similar to that of 'Great Lakes 659-700', but that of 'Prize Head' was significantly lower (Table 4).

Seeds germinated faster on $\mathrm{SH}$ medium with $1.5 \%$ glucose, $0.54 \mu \mathrm{M}$ NAA, and 0.44 $\mu \mathrm{M}$ BA than on SH medium with $3 \%$ instead of $1.5 \%$ sucrose, but the seedlings had succulent cotyledons and small roots (data not shown). Explants excised from the succulent cotyledons regenerated shoots within 2 weeks on the same medium. Compared to the medium with $3 \%$ sucrose, $0.54 \mu \mathrm{M}$ NAA, and $2.3 \mu \mathrm{M}$ kinetin, the medium with $1.5 \%$ glucose, and the rest the same, saved $\approx 10$ to 14 days from seed germination to shoot regeneration.

\section{Literature Cited}

Alconero, R. 1983. Regeneration of plants from cell suspensions of Lactuca saligna, Lactuca sativa, and Lactuca serriola. HortScience 18:305-307.

Doerschug, M.R. and C.O. Miller. 1967. Chemical control of adventitious organ formation in Lactuca saliva explants. Amer. J. Bot. 54:410413.

Kadkade, P. and M. Seibert. 1977. Phytochromeregulated organogenesis in lettuce tissue culture. Nature 270:50-51.

Koevaxy, K., L. Rappaport, and L.L. Morris. 1978. Tissue culture propagation of head lettuce. HortScience 13:39-41.

Maretzki, A., M. Thorn, and L.G. Nickell. 1974. Utilization and metabolism of carbohydrates in cell and tissue culture, D. 329-361. In: H.E. Street (ed.). Tissue culture and plant science. Academic, New York.

Murashige, T. and F. Skoog. 1962. A revised medium for rapid growth and bioassays with tobacco tissue cultures. Physiol. Plant. 15:473497.

Nishimura, M., H. Naraku, and L. Iwazaki. 1988. Artificial seed, Jpn. patent 63-133904.

Nishio, T., T. Sato, K. Mori, and K. Takayanagi. 1988. Simple and efficient protoplast culture procedure of lettuce, Lactuca sativa L. Jpn. J. Breeding 38:165-171.

Sasaki, H. 1975. Physiological and morphological studies on development of vegetable crops. III. Adventitious bud formation of callus tissues derived from lettuce hypocotyl. J. Jpn. Soc. Hort. Sci. 44:138-143.

Sasaki, H. 1979. Physiological and morphological studies on development of vegetable crops. VI. Effect of several auxins, cytokinins and cytokinin-ribosides on the adventitious bud formation of lettuce hypocotyl tissue cultured in vitro. J. Jpn. Soc. Hort. Sci. 48:67-72.

Schenk, R.V. and A.C. Hildebrandt. 1972. Medium and techniques for induction and growth of monocotyledonous and dicotyledonous plant cell cultures. Can. J. Bot. 50:199-204.

Webb, D.T., L.D. Torres, and P. Fobert. 1984. Interactions of growth regulators, explant age and culture environment controlling organogenesis from lettuce cotyledons in vitro. Can. J. Bot. 62:586-590. 